\title{
Robot technologies, autism and designs for learning
}

\section{Mikala Hansbøl}

$\mathrm{PhD}$, Docent

FoU-miljøet Digitale læringsressourcer

Institut for Skole og Læring

Det Samfundsfaglige og Pædagogiske Fakultet

Professionshøjskolen Metropol

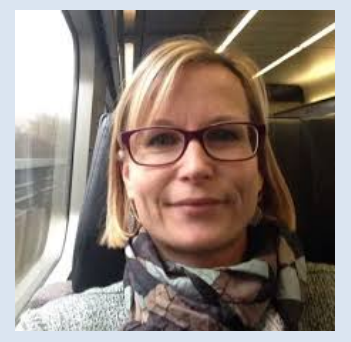




\section{Abstract dansk}

Feltet robotteknologier og uddannelse er et mega-expansivt felt. I løbet af kun få år, internationalt og i Danmark, er fokus på uddannelsesrobotter og robotteknologi i uddannelse øget markant. 2015 NMC Technology Outlook rapporten tilbyder et teknologi udsyn i de skandinaviske lande, og her placeres robotteknologi og programmering inden for en fire-fem årig adoptionsperiode. I Danmark igangsætter mange kommuner forsøg med robotteknologi i skoler og dagtilbud, og der investeres i mange forskellige robotteknologier. Området uddannelse og robotteknologi involverer flere forskellige tilgange til udvikling af robotteknologi, nye uddannelsesmuligheder og til at understøtte børn og unge menneskers læring og udvikling. Artiklen diskuterer hvordan robot teknologier relateres som læringsressourcer til feltet autisme og uddannelse. Med fokus på børn og unge diagnosticeret med autisme spektrum forstyrrelser, deres it-interesser og engagementer i innovativ og kreativ læring, argumenterer artiklen for et behov for at udvide tilgangen til dette felt $\mathrm{i}$ fremtiden. Artiklen relaterer international forskningslitteratur med fokus på robotteknologi og uddannelse til empiriske eksempler fra forfatterens egen forskning i uddannelse for børn og unge diagnosticeret med autisme spektrum forstyrrelser. Det empiriske afsæt er her læreres og elevers interesser $\mathrm{i}$ at arbejde med it (fx robotteknologi).

\section{Abstract engelsk}

The field of robot technologies and education is rapidly evolving. Within only a few years, internationally and in Denmark, the focus on educational service robots and educational robotics has become more widespread. The 2015 NMC Technology Outlook report providing a technology outlook on Scandinavian schools places robotics and programming within a four to five year time-to-adoption period. At the moment in Denmark, many municipalities are initiating trials, investing in and engaging a diverse range of robot technologies in both daycare and schools. The field of education and robot technologies involves several very different educational approaches to supporting young people's learning and development. The paper discusses how robot technologies as learning resources have been related to the field of autism and education, and argues for a need to further expand the areas of application in the future, with a focus on children and young people diagnosed with autism spectrum disorders, their ICT interests and engagement in innovative and creative learning. The paper draws on international research and examples from the author's own research into education for children and young people diagnosed with autism spectrum disorders, drawing on teachers' and the students' interests in working with ICT (e.g. robot technology). 
Keywords: robot technology, educational robots, educational robotics, autism spectrum disorders, designs for learning, ICT interests and engagements, skills training, innovative and creative learning.

\section{Setting the scene}

The World Health Organization (2016) classifies autism as a pervasive developmental disorder, a classification applied when dysfunctions fall into at least two of the following categories: "specific developmental disorders of speech and language", "specific developmental disorders of scholastic skills" and "specific developmental disorder of motor function". The pervasive developmental disorders include "childhood autism", "atypical autism", "Rett syndrome", "other childhood disintegrative disorders", "overactive disorder associated with mental retardation and stereotyped movements" and "Asperger's syndrome". According to the Danish Association for Autismi about one percent of the Danish population has an autism spectrum disorder. The figure is higher in other countries, such as the United States and South Korea (Cabibihan, Javed, Ang Jr. and Sharifah, 2013). The term "autism spectrum disorder" is a term covering all the diagnoses classified as pervasive developmental disorders. This is the preferred term today, as "autism" fails to convey that autism exists in multiple forms.

Naturally, a diagnosis of autism spectrum disorder only characterizes some dimensions of what it means to be human. Being human embodies far more than any diagnosis can convey. I choose to write dis/ability because I want to emphasize that whenever someone is diagnosed with a disorder, the diagnosis highlights particular modes of dysfunction - ways of "not being in order" and "not being able". Like all of us, however, people living with autism spectrum disorders have a multiplicity of being both able and disabled. It is, as this paper will illustrate, important to refrain from drawing the hasty conclusion that a diagnosis defines how the full individual who receives it generally functions or not. A diagnosis of autism spectrum disorder is a cultural and historical matter specified in various ways that have changed over the course of history and across cultures (see, e.g., World Health Organization, 2016).

Autism is mostly described as encompassing a triad of core impairments in the spheres of 1) social relationships/interaction, 2) social communication and 3) imagination (Cabibihan et al., 2013). The World Health Organization's classifications and diagnoses of autism spectrum disorders are based on a deficit-oriented definition that points out the dysfunctions in a person's psychological development. Defining a person by this diagnosis thus reduces him or her to a finite set of characteristics and positions these characteristics as deficits.

In the case of the school-aged child or young person, basing our understanding of this student as an individual with certain deficits may therefore too easily translate into notions about what designs for learning are the most important 
and appropriate for this kind of student. Ideas about the best designs for learning for children and young people diagnosed with autism spectrum disorders may thus be translated into representative digital learning resources targeted at this particular group.

While digital learning resources developed for and targeted at children and young people diagnosed with autism spectrum disorders may be useful in educational activities for particular students, I hope that this paper will clarify why we also need to engage with students diagnosed with these disorders as whole and individual human beings who - like any other student - embody a complex multiplicity of dis/abilities and dis/engagements related to their personal interests and the daily course of their lives. A failure to pay attention to these heterogeneously constituted articulations of their dis/interests, competencies and preconditions can give rise to problems and - more importantly - would be a huge societal mistake.

In this paper I will focus on some of the students and teachers I have met in two educational institutions. I will discuss the kinds of information and communication technology (ICT) interests and engagements they represent, and how these interests and engagements relate to the area of engaging robot technologies as educational technologies for children and young people diagnosed with autism.

The subject of this paper might appear slightly at odds with this special issue of Learning and Media (LOM), because it focuses less on robot technologies in practice and more on how to create relationships between robot technologies, education and children and young people diagnosed with autism spectrum disorders. I see robot technologies in education as another means of engaging with ICT in education. I find it important to remember that new ICTs (e.g., touch screen technologies - interactive whiteboards, smartphones and tablets) enter education all the time. We must therefore view robot technologies as partially coexisting with an array of other education technologies, some of which we define as digital technologies and others as information and communication technologies. Hence, to study the possible interrelation between robot technologies and education for children and young people diagnosed with autism spectrum disorders, I connect with the broader issues of ICT and learning in education. I further relate the increasing focus on robot technologies in education to the also increasing focus on students' technological literacy. These trends are not isolated, a fact I believe we should bear in mind when we engage with new digital technologies in education.

There is a tendency to enact new digital technologies for education as if they were entirely new actors with entirely new prospects for education. Like any technology, however, robot technologies come into being in education through and not apart from already existing educational entanglements. This is a 
fundamental premise. The question is how do new digital technologies become enacted as educational actors in and across various educational contexts of activity?

\section{Enactments of dis/abilities of robot technology}

In 1996 McDermott published the seminal article "The acquisition of a child by a learning disability". This groundbreaking article claimed that it is important to understand how culture dis/ables. McDermott pointed at the importance of paving new ways of understanding human capacities. By connecting disability with culture, McDermott wanted to move away from disability conceived as a deficiency in capacity, towards disability conceived as connected with history and situation. McDermott also aimed to move away from the conception of disability as a purely interior deficiency with no place in everyday life. Inspired by McDermott's approach, this paper puts dis/ability in the middle of culture, and views learning as a ubiquitous aspect of everyday living. Following this thinking, we can view shifting knowledges, instruments, forms of organization and techniques as also involving shifting dis/abilities.

In this context the learning and teaching situation is understood as always more than the substance of teaching moments, and acknowledged as involving more than students and teachers as the central actors. Because various human and non-human actors and their different trajectories of (co-)participation co-define teaching and learning situations in this approach, they always involve multiple sociomaterial orchestrations of doing-being learning and teaching.

Verran (2007) has pointed to the importance of attending to how various phenomena are sociomaterially enacted and hence must always be understood as political. By being attentive to phenomena as sociomaterial, political enactments, it becomes possible to articulate alternatives. Drawing on McDermott and Verran, this paper analyses the enactments of dis/abilities of robot technology in general and special education. The background for this paper is my preject in which I qualitatively worked my way into and opened the field of robot technology, autism and education. Darsø (2011) defines "preject" as a mode prior to an actual project mode. The preject mode emphasizes being "open, uncertain and possibilityseeking".

In this paper I will present my exploratory reading of Danish and international research ${ }^{\mathrm{ii}}$ and research into education (primary, lower and upper secondary school) for children and young people diagnosed with autism spectrum disorders. I draw on teachers' and students' own perspectives on, interests in and proconditions for working with information and communication technologies (ICT). The empirical data collected include exploratory semiformal observations (micro- 
ethnographic snapshots) of situations in school and interviews with students and teachers from two different educational institutions for children and young people diagnosed with these autism spectrum disorders in Denmarkiii.

Throughout the paper, I will endeavor to challenge the configurations of robot technologies, education and children and young people diagnosed with autism spectrum disorders that I have (so far) encountered in literature. I draw on McDermott, Verran and my own (Hansbøl, 2010) relational materialist (inspired, e.g., by Bruno Latour, e.g. 1999 and 2005; Marilyn Strathern, 2004; De Laet and Mol, 2000; Annemarie Mol, 2002; and Casper Bruun Jensen, 2004) research into enactments of relationships between ICTs and education in an everyday perspective. In taking this approach, I acknowledge that technology always is and becomes technology-through-sociotechnical-systems.

In other words, I also see it as a central aspect of my work to challenge and develop how we understand "technology" and its entanglements in practice - how technology comes to "participate", to gain "agency", "capacity" and "dis/ability" in research as well as in everyday educational activities. Through these alignments, I endeavor to open up discussions of the existing knowledge and knowledge practices regarding robot technologies, autism and education. With this approach, I follow central questions like what is robot technology when it comes to dealing with autism and educational matters? How does existing research (con)figure and articulate children and young people diagnosed with autism spectrum disorders and robot technologies? How does research contribute to the development of inclusion practices and educational practices? To what benefit? For whom? Under which circumstances? In which contexts?

\section{Robot technology in Danish schools}

The field of robot technology and education is rapidly evolving. Within only a few years, internationally and in Denmark, the focus on robot technologies and education has become more widespread. The 2015 NMC Technology Outlook report (Johnson, Adams Becker, and Hall, 2015) places robotics and programming within a four to five year time-to-adoption period in Scandinavian schools. At the moment in Denmark, many municipalities ${ }^{\text {iv }}$ are initiating trials, investing in, and engaging a diverse range of robot technologies in both daycare and schools.

In Denmark, there has been a relatively high emphasis on ICT and media in primary and lower secondary schools, but in recent years greater focus has been put on students' technological literacy - including their education, Bildung and competencies. The assumption for many years was that the widespread integration of ICT and media in teaching activities enhanced students' technological literacy. Furthermore, it was anticipated that the 
more general embeddedness of ICT and media in everyday Danish life would create new generations of digitally native children and young people imagined to act as fluent and creative media producers. Two recent surveys ICILS 2013 (Bundsgaard, Petterson and Puck, 2015) and Fablab@Schools 2015 (Hjorth et al., 2015), however, have highlighted that Danish students (aged 11-15) are far less technologically literate than expected. The Fablab@Schools survey also confirms the tendency for students to be more ICT- and media-consuming than media-producing.

The new Danish school reform (in effect from the 2015/2016 schoolyear) covering municipal primary and lower secondary education emphasizes more transversal competencies with a focus on innovation and entrepreneurship. The new reform states that future citizens need to be able to create and design. These competencies are also referred to as $21^{\text {st. }}$ century skills (e.g. UNESCO, 2008). Twenty-first-century skills can broadly be described as basic competencies within three main areas: life and career competencies, learning and innovation competencies and ICT, media and technology competencies (e.g. OECD, 2009 and Partnership for 21st Century Learning, 2007). The recent increased focus on robot technology, programming, coding and computational thinking in schools can be understood as closely related to these reforms intended to engage schools actively in teaching activities that foster students' technological literacy and innovation competencies. Although these aims weigh heavily in much of the rhetoric surrounding efforts to bring robot technology into schools, robot technologies are also cited as a means of promoting efforts to increase instructional efficiency.

Alimisis suggested in 2009 that a need exists to develop designs for learning with robot technologies. This is no less true in a Danish school context today, where the recent increased focus on developing manifold robot technologies for education and the greater investment in and attention to a wider variety of robot technologies in Danish primary and secondary schools has given rise to new needs and angles to this work. Hence, in a Danish context teachers' and schools' competencies for working with as well as re-imagining work with robot technologies as educational technologies in both general and special education still needs to be developed. Furthermore, there is a need for critical reflection on how to institute and expand the use of robot technologies in schools. In an interview (Ebdrup, 2014), Cathrine Hasse, a Danish professor and head of the research program Future Technology, Culture and Learning, reports that 40 Danish primary schools invested in the (at the time) rather expensive humanoid robot Nao as an assistant teacher to aid in teaching math, Danish and English skills. They realized, however, that while the robot as a figure fascinated the children, it was not terribly successful at acting as a teaching assistant. Instead, Nao proved more useful as a means of teaching programming skills. 
There is an ongoing need to ask questions like: What kinds of robot technologies are brought into schools? With what aims? What are the learning potentials for whom, with what robot technologies and under what circumstances? As the recent OECD report "Students, Computers and Learning - Making the Connection" (2015) also set in stone: it is not a natural given that adding ICT to educational activities also adds to learning as needed and intended. The relationship between ICTs and learning is complex.

\section{Enactments of robot technology as educational technology}

Brogaard Bertel, Rasmussen and Christiansen (2013) identify two overall approaches to robot technologies in education: "Educational robotics" (hands-on robotics) and "educational service robots" (social, anthropomorphized robots as teaching assistants). Educational robotics has been associated with constructionist (Seymour Papert, e.g., 1990, 1993a and 1993b) approaches to teaching and learning, and has been researched with relation to this theoretical approach, whereas educational service robots have been more closely associated with instructivist, cognitivist and behaviorist approaches to understanding teaching and learning.

Today, the development of robot technologies for education is truly becoming a vast ocean, with the focus being on fostering play, learning and development via robot technologies. Many variations of educational service robots (e.g., Nao, Zeno, Romibo and VGO) are emerging with programs and curricula for various activities and school subjects within both general and special education. The area of educational robotics is also an emerging market. Many construction sets (e.g., Lego Mindstorms, and Youbot, Ez Robots and Vex Robotics for science teaching), production robots (e.g., 3D printers) and also humanoid robots (e.g., Nao, KASPAR) are entering the education market ${ }^{v}$.

Each robot technology offers professionals and students a range of creator options for designing and developing their own programs and constructing activities. Robot technologies are multifunctional, and the same robot technology might both come with predefined programs and areas of use and be open to the user explorations of use (as we saw in the example above with schools engaging with Nao). Some technologies are vaguely defined at the outset, leaving it up to the users to define practices and use the scenarios of relevance to them. The following table provides an overview of some of the different educational settings, curriculum areas and the different creator options for students and professionals. As with other digital learning resources, the field is large: 


\begin{tabular}{|l|l|l|l|}
\hline $\begin{array}{l}\text { Educational } \\
\text { setting }\end{array}$ & Curriculum & $\begin{array}{l}\text { Creator options } \\
\text { for students }\end{array}$ & $\begin{array}{l}\text { Creator options } \\
\text { for professionals }\end{array}$ \\
\hline $\begin{array}{l}\text { Play, learning } \\
\text { development }\end{array}$ & None & None & None \\
\hline Unspecified & $\begin{array}{l}\text { Subject-specific } \\
\text { knowledge, skills } \\
\text { and competencies. }\end{array}$ & $\begin{array}{l}\text { "drag and drop" } \\
\text { (easy } \\
\text { programming and } \\
\text { construction) }\end{array}$ & $\begin{array}{l}\text { "drag and drop" } \\
\text { programming and }\end{array}$ \\
\hline $\begin{array}{l}\text { Daycare } \\
\text { Primary school }\end{array}$ & $\begin{array}{l}\text { Transversal } \\
\text { knowledge, skills } \\
\text { and competencies. }\end{array}$ & $\begin{array}{l}\text { It-nerd } \\
\text { (complicated } \\
\text { programming and } \\
\text { school }\end{array}$ & $\begin{array}{l}\text { construction) } \\
\text { It-nerd }\end{array}$ \\
\hline $\begin{array}{l}\text { Upper secondary } \\
\text { school, etc. }\end{array}$ & $\begin{array}{l}\text { congamming and } \\
\text { construction) }\end{array}$ \\
\hline
\end{tabular}

Table 1: educational settings, curriculum areas and creator options

What is special about the area of robot technology as educational technology is the often strong focus on making technology work, e.g., through coding, programming, scripting and constructing technology. Working with robot technologies in education is often quite demanding for both professionals and students when it comes to understanding technology and having the proficiency to handle it. Based on a review by Mubin, Stevens, Shahid, Mahmud and Dong (2013), the following table illustrates some of the different ways of engaging with the applicability of robot technologies in education:

\begin{tabular}{|l|l|}
\hline Subject of teaching & $\begin{array}{l}\text { Language, science and STEM subjects, practical-musical } \\
\text { subjects, }\end{array}$ \\
\hline $\begin{array}{l}\text { Approaches to robot } \\
\text { technologies }\end{array}$ & Learning with, about and from robot technology \\
\hline $\begin{array}{l}\text { The role of robot } \\
\text { technology }\end{array}$ & $\begin{array}{l}\text { Tool (passive role), (more active roles) peer, co-learner, } \\
\text { tutor, companion }\end{array}$ \\
\hline Arguments & $\begin{array}{l}\text { More entertaining, engaging approaches to learning, play } \\
\text { and learning, greater student interest in subjects, ownership } \\
\text { and more effective learning }\end{array}$ \\
\hline Special characteristics & $\begin{array}{l}\text { Embodiment - physical presence, other options for social } \\
\text { interactions than, e.g., traditional software. }\end{array}$ \\
\hline
\end{tabular}




\begin{tabular}{|l|l|}
\hline $\begin{array}{l}\text { Selection of robot } \\
\text { technology }\end{array}$ & $\begin{array}{l}\text { Depends on price, costs, subject, students' age, pedagogical } \\
\text { approach, technological complexity }\end{array}$ \\
\hline $\begin{array}{l}\text { Didactic approach / } \\
\text { approach to learning }\end{array}$ & $\begin{array}{l}\text { Constructionism (Papert), constructivism (Piaget), social } \\
\text { constructivism (Vygotsky) - scaffolding how to think, solve } \\
\text { problems, construct and be creative }\end{array}$ \\
\hline Didactic principles & $\begin{array}{l}\text { Most in focus: active learning, learning via design, hands-on } \\
\text { approaches }\end{array}$ \\
\hline Challenges & Lack of curriculum and learning materials \\
\hline
\end{tabular}

Table 2: Applicability of robot technologies in education

\section{Robot technology as educational technology in general and special education}

In 2006 Kärnä-Lin, Pihlainen-Bednarik, Sutinen and Virnes noted that "Educational robotics is used worldwide in education as a learning tool, but surprisingly rarely in special education ... When used [sic], student's role is often to work as a user of technologies instead of the role of doer, controller or creator of a technology." When searching for Danish and international literature on "robot technology and education" today, one finds the field is - as illustrated in the above - enacted as complex and manifold. However, using this search phrase primarily results in references to research and development projects within general education, with a clear overweight of literature focusing on educational robotics. The search phrase "robot technology and autism" in contrast primarily results in references to literature focused on educational service robots (social robots) and their therapeutic potential. This has also been noted by Majgaard, Hansen, Bertel and Pagh (2014). Experiences with and knowledge about working with robot technology in education appear to be generated quite differently when it comes to general and special education.

When reading literature on robot technology and autism, one finds the focus is typically on what skills (e.g., communicative, social) technology can teach children. In this area, the emphasis is on developing robots that can help "children in their social, emotional, and communication deficits" (e.g., Cabibihan et al., 2013). Literature focused on robot technology and general education highlights educational robotics, technological literacy, innovative and creative learning and the student's role as producer (what can children teach technology), while literature on robot technology and autism highlights educational service robots, skills training and the student's role as a user (what can technology teach children). This is particularly interesting, as seen in the previously mentioned example with Nao, which 
illustrated that in general education, schools in Denmark have found that Nao as an educational service robot does not work in practice.

The 2015 NMC Technology Outlook Scandinavian Schools report (Johnson et al., 2015) also illustrates the difference in emphasis between robot technologies in general education and in special education. According to the report, the potential applications of robotics are vast, e.g., as a way to "encourage students to take an interest in the fields of engineering and programming" and "coding helps instill more critical thinking and creativity in students". Robotics may also be used to "teach young learners how to develop mobile apps and games". However, mentions of special education relate to autism and are worded with formulations like "students with spectrum disorders are more comfortable working with robots to develop better social, verbal, and nonverbal skills" and "A robot at Birmingham's Topcliffe Primary School helps autistic children develop social interaction skills by emitting encouraging responses without the confusion of non-verbal cues." (p. 18)

It seems, that much of the research into autism, robot technologies and education has been conducted with children with significant difficulties and within the frames of social robotics research (see, e.g., Cabibihan et al., 2013). Wainer, Dautenhahn, Robins and Amirabdollahian (2014), for instance, report on a pilot study with a novel setup for the collaborative play of the humanoid robot KASPAR with children with autism. This study uses "tests" and "experiments" as well as compares an engagement with an adult versus that with a humanoid robot (KASPAR):

\begin{abstract}
"Research has shown that humanoid robots, whether used as toys programmed to dance to specific pieces of music or remotelyoperated robotic 'puppets', can promote imitative free-form play among pairs of children with autism [49].
\end{abstract}

Additionally, such robots can also foster triadic interactions among themselves, a child with autism, and a human experimenter [47].

Such behaviours are necessary in order for children to engage in social play, a form of play in which children with autism have significant difficulty participating due to the social impairments that are characteristic of their disorder [28] ..."

Wainer, Dautenhahn, Robins and Amirabdollahian (2014)

Brogaard Bertel et al. (2013) identify this kind of research as dominant - so far - within the field of social robotics and autism. The social robotics research studying educational service robots and autism has centered on experimental setups that bring together (mostly) a child/children, the http://www.lom.dk 
educational service robot and an adult caregiver (teacher/therapist) and researcher in a safe and enclosed environment where the focus is on dyadic and/or triadic relationships.

When one looks at how relationships between robot technologies, education and autism are enacted, it appears that only "one" research approach has been taken and that the door to the many possibilities and reasons for engaging robot technologies in educational activities has been very small. The current approach focus on deficits and aims at "removing human noise" and comparing how children engage with social robots and with humans in experimental situations. Like Alimisis and Kynigos (2009), research dealing with general education and robot technologies seems to focus on the active and able student engaging in learning through design and construction processes with many different kinds of robot technologies. The following table illustrates the different ways of engagement. The red text highlights the main emphasis in general and special education, respectively:

\begin{tabular}{|l|l|l|}
\hline Education & $\begin{array}{l}\text { Educational robots } \\
\text { Cognitive training, } \\
\text { play and learning }\end{array}$ & $\begin{array}{l}\text { Educational robotics } \\
\text { and learning }\end{array}$ \\
\hline Normal & $\begin{array}{l}\text { Teaching assistant - } \\
\text { e.g., English, Math }\end{array}$ & $\begin{array}{l}\text { Digital Bildung / } \\
\text { programming / } \\
\text { technological } \\
\text { literacy }\end{array}$ \\
\hline Special & $\begin{array}{l}\text { Therapeutic (social } \\
\text { and communicative } \\
\text { skills, learning } \\
\text { rules) }\end{array}$ & $\begin{array}{l}\text { Digital Bildung / } \\
\text { programming / } \\
\text { technological literacy }\end{array}$ \\
\hline $\begin{array}{l}\text { Instructivist, } \\
\text { Cognitivist / } \\
\text { behaviorist }\end{array}$ & Constructionist \\
\hline
\end{tabular}

Table 3: Ways of engaging robot technologies in special and general education

\section{Research with a focus on robot technologies as educational technologies}

Social robotics appears to be a research approach that heavily influences how relationships between robot technologies, education and children and young people diagnosed with autism spectrum disorders develop. Social robotics approaches in research literature are manifold and include a variety of disciplinary backgrounds as well as theoretical inspirations, the 
two main ones being HRI (Human Robotics Interaction) and STI (Science, Technology and Innovation studies). HRI- and STI-inspired social robotics literature often center on the development of the socially capable robot in fixed human-robot situations (Brogaard Bertel et al., 2013). The focus is on the robot itself and not on how it becomes an actor in and across different societal situations. STI and HRI are not fixed research approaches, though, and they encompass different methodologies, some of which are more closely associated with participatory design and anthropological approaches (e.g. Brogaard Bertel et al., 2013), while other research approaches relate more closely to cognitively oriented clinical research and clinical experiments (e.g. Wainer et al., 2014).

Brogaard Bertel et al. (2013) suggest that the social robotics field pertaining to education thus far has not emphasized the everyday aspects and contexts of robot-articulation work. The authors state that the field of research into social robotics could gain from drawing on anthropologically oriented research and design anthropology, and that participatory design approaches could serve as sources of interest - mostly for the purpose of placing the articulation work of relating robots to education in everyday and ongoing educational activities. Castañeda and Suchman (2014) also stress the importance of delving into the work of figuring and refiguring robots. The authors point at the importance of acknowledging that different articulations of robots take part in bringing them - and hence also their capabilities - into being. They call this a process of corporealization. The work of assembling the corpus of robot technologies and education has a fundamental impact on what becomes of robot technologies and education.

Brogaard Bertel et al. (2013) suggest that participatory design can contribute to social robotics and HRI research, as it opens the ways in which time, space and structure become (often pre-)defined in HRI research. The authors suggest that it is important to invite different figurations and reconfigurations of time, space and structure into research and that these should be more emergent in character and should include the actual users and co-designers of robots, robot-learning and robotdidactic design as they appear through everyday educational practices. In a real-life setting, as Brogaard Bertel et al. (ibid.) emphasize, the relationships that may come to the fore are much more contextually manifold and complexly interrelated with aspects such as knowledge, relations, educational values, students' and teachers' heterogeneous interests, preconditions for teaching and learning, etc., and hence situated within as well as distributed across the overall "educational environment" and "educational situation" of the particular students expected to be learning with robot technologies. Furthermore, the same authors point to the need to include not only the perspective but also the active participation of the professionals meant to develop, engage and legitimize http://www.lom.dk 
engagements with robot technologies in the everyday educational activities. To this I would add the importance of including the perspectives and active participation of the students, their interests, engagements, aspirations, etc.

The point here is to articulate and emphasize the importance of having an awareness of the different approaches to research on robot technologies as educational technologies - one approach being to develop social robots for skills training in education, and another to develop educational capacities for engaging with robot technologies that focus on technological literacy and innovative and creative learning in education. In this paper, I ascribe to the latter approach, wishing to add to already existing movements that draw on anthropologically oriented research, design anthropology and participatory design approaches to research robot technologies as educational technologies.

The aim of the paper is to broaden the horizon by providing another approach to understanding the teaching and learning potential of including ICTs such as robot technologies in the educational everyday arrangements targeted at children and young people diagnosed with autism spectrum disorders. More specifically, I shift the focus to children and young people with self-declared interests in ICT and multifarious capacities for engaging creatively with ICTs. For the purpose of this paper, I focus on the aspirations, ICT interests and proficiency of students in educational institutions targeted at children and young people diagnosed with autism spectrum disorders.

\section{Future aspirations and ICT interests}

In the following I turn my gaze towards an everyday teaching situation in a Danish upper -secondary education program vi for young people diagnosed with autism spectrum disorders. I engage with excerpts from semiformal individual interviews, which I conducted in 2012 with three students named Violet, Michael and Peter. The education program is aimed at - in many ways - quite well-functioning young people diagnosed with Asperger's and other variants of autism spectrum disorders - young people that will most likely be able to have jobs and their own private homes. The education program is targeted at young people with a particular interest in ICT. The excerpts focus on the students' aspirations, ICT interests and competencies.

Violet is a student whom teachers describe as having ICT capacities. I make the same observation in the computer programming class and a Lego Mindstorms class, where she contributes actively to the construction work (by programming with software and constructing a machine with various Lego Mindstorm hardware parts that can move around in a circle and collect Lego men). Violet is a 21-year-old woman who dreams of 
contributing to the future development of professional IT systems and thereby professional practices:

"I believe that the dream situation for me would be if I created a genius program, earned a lot of money, moved to the countryside with a husband and perhaps a child - and lots of animals in the garden and an unlimited internet connection... I have worked with quite a few professional programs where I thought, 'This is screwed up. Why is this not an option?' Programs where you need to push twenty places, in order to enter a menu. I will think, 'Why do they not have a favorite? Right there at the side together with the six functions that we are only allowed to use, anyhow.' This requires that you get access to working with the professional programs or that you make it from the ground up ..."

Michael is 18 years old. He is interested in "inventing something new" and explains that whenever you invent something new related to ICT, it needs programming to begin with. In order to produce something original, Michael explains, one must invent a new idea or use earlier concepts in a new way. This is difficult, however, as so much has already been invented. Michael would like to work on creating new concepts. Not so much generating the actual ideas, he explains, but making the ideas work in practice. Michael likes doing new things and appreciates a challenge. When asked about what job Michael would be interested in having, he answers that variation is crucial: "... I really cannot handle doing the same thing over and over again." When I visit the classes that Michael is in, his teachers and fellow students consistently describe him as a very resourceful and ICTcompetent student. When entering the upper-secondary education program, Michael was already developing small ICT programs:

"I had made a tiny program, ... an auto clicker that works all too well. In some games you have a lot of very repetitive tasks where you need to sit and push the mouse button a lot of times. Then I made an auto clicker for these tasks ... it is not exactly something entirely new, but I have made it differently from a lot of other auto clickers. Most people, when they make auto clickers, they make them unnecessarily complicated."

The interview with Michael illustrates that repetitive ICT work may not always be the aspiration of a person like him, who is a very resourceful, competent and knowledgeable when it comes to ICT. Michael is also interested in ICT on a conceptual and design level. Michael and Violet show proactive attitudes towards ICT in the sense that they are interested in scrutinizing the construction of ICT systems and contributing to further developing more advanced future systems.

Peter is very interested in fixing computers. He has been fixing computers since he was 12. At the time of the interview, he had been working for two years in the IT department of a large international company in Denmark, as http://www.lom.dk 
part of his upper-secondary education program. As Peter explains it, he is working in a place with a particular IT-culture - characterized by a sense of humor, a strategy of working around and with things and collegial collaboration on fixing things. Peter explains that the school part and the work part of his youth education program differ in their access to authentic hard- and software with the right capacities, and in terms of being an actual member of and contributing to the IT culture and the actual work of the IT department. Through working in the company, Peter has gained work experience as a troubleshooter and as a helpdesk for people working with servers, assisting those without the competencies for setting up servers and computers, fixing failures, formulating step-by-step instructions, testing and examining hard- and software. He has collaborated with colleagues sharing the same interests and knowledge. Peter is particularly fond of providing frontline support:

"I find frontline support - sitting and helping users - particularly exciting... They are supposed to call me, and then I figure out what is the matter...The support also depends on the priorities, and they may change all the time. Suddenly there might be an unforeseen urgent task. For instance, if a screen suddenly dies, then I must prioritize that over something else that may have been the first priority before. My top priority must be the people who cannot do their work...."

Peter's examples illustrate the necessity of thinking creatively and being curious about the inner workings of different IT systems:

"... we had a home server that did not cooperate with us ...Then we may be several colleagues sitting together, brainstorming. Every time we have been out on a case, we hold a meeting about the work and different ideas that came up. In the department we focus a great deal on knowledge-sharing. If I have something important to tell my colleagues, then I tell them or send an email describing the issue. We might have a conversation, I tell them about my ideas, they share their perspectives and then we agree on something together, if that is what it takes..."

In Peter's story, the processes of work (the ability to make priorities, communicate and collaborate with more knowledgeable colleagues, etc.) stand out as being as important as the technical aspects of the IT work requiring ICT skills. The three stories of Violet, Michael and Peter illustrate that their ICT interests, aspirations and experience differ. ICT is each of these three young people's particular area of interest. However, they have interests other than ICT skills in the sense of becoming familiar with and being able to handle systems. They are not interested in programming in itself, and they are not interested in ICT as a tool for learning other subjects of teaching either. They are eager to learn about ICT, variously motivated, e.g., by an interest in fixing systems and their bugs, designing better 
programs and systems, and (thereby) helping other (professional) people using and developing systems.

What I want to convey with these examples is how differently technology, education and students diagnosed with autism spectrum disorders are positioned compared with the way that social robotics researchers position robot technologies with autism in the above examples. These students are young, highly intelligent and in many ways competent individuals who program and actively produce and contribute to the development of technology or other people's use of technology. The three students come up with creative and innovative solutions and take part in defining what computers should do - e.g., through programming - rather than having computers tell them what to do (as is roughly the case when students work with educational service robots like KASPAR).

\section{ICT interests and preconditions for learning}

In the following section, I change the scene to another educational institution (primary and lower secondary education) for children and young people diagnosed with autism spectrum disorders. I draw on exploratory observations of situations in school and semiformal interviews and conversations with teachers and one student. I visited the school in 2015 as part of some exploratory studies aimed at formulating a research and development project on the prospects of engaging robot technologies in school teaching activities. The teachers I met described the teaching activities for these children and young people diagnosed with autism spectrum disorders as involving the special challenges of:

- engaging and motivating students

- getting students to stay focused

- getting students to engage with activities driven by external motivation

- getting students to engage with perspectives other than their own

- getting students to take initiative and to be creative and inventive

When I visited the school, they had already tried to work with the humanoid robot Nao as a teaching assistant in connection with a collaboration with a Danish robotics company. The activity involved testing and further developing a program originally developed for children with autism in the United States and aimed at training communication skills. In the experience of the Danish teachers the program did not catch their students' interest. The teachers described the approach of using the robot as an assistant for training students' skills as very limited. One teacher 
explains: "It sounded interesting, but hours of programming grew into tasks that would in practice take a few seconds for our students to carry out."

One problem with the setup, the teachers explain, was the target group for the program was unclear. What kinds of students? The teachers explain that they experience students in their schools that are highly interested in ICT, competent and motivated. For instance, students that spend a lot of hours on Minecraft. The teachers see interesting possibilities in engaging these students' active ICT interests and skills in their teaching activities. Rather than training skills with a robot as instructor, they would like to engage with robot technologies as a means of enhancing the students' technological literacy as well as their innovative competencies. One teacher explains that a lot of the students have digital competencies and spend a lot of time online, which would be an excellent place to start and useful as a common third - a way of pedagogically approaching and engaging in conversations with students and in shared activities that scaffold reflections and develop competencies like problem-solving, communication, design and innovation. The teacher also explains that a focus on social and communicative competencies could much more meaningfully be based in the students' actual active engagements in various ICT activities that are already a natural part of their young daily lives. Programming robots could offer another possible entrance to these engagements. Another teacher supplements by telling about students that do Java programming and develop items like dragon eggs for Minecraft. He tries to include this in his math activities by initiating talks in class about concepts related to what the students are building (e.g., illustrating their spatial competencies).

In this school I meet a boy who is new to the school and at the moment staying at home. I will call him Adam. According to the teacher, this boy spends a lot of time on the computer. The teacher thus figured that he could talk with the student via Skype when he was absent. In a Skype conversation, the student agrees to show me what he is working on. When asked how he has learned to do all this, he answers YouTube and other online resources. Via Skype Adam tells me:

"At the moment I mostly do two things. Webapps and homepages. I have also been doing a little bit of Basics and C Sharp programming... This is [showing me on screen]... not finished, at all! This is the start page, so far. I do not exactly know how it is going to look. I am coding it in HTML, CSS and Javascript, which is what you use for making normal homepages, then I also use another code to make it a little more advanced ... I have also made a small web application written in Javascript, where you can add a telephone number and then add the link to your homepage and choose whether people can call you via Skype, send an SMS, or telephone ... depending on whether you enter the page from a mobile phone or a computer, the options will differ. 
I have also enabled the start page to check which operating system the user is using, so that the page will automatically generate the right download button relevant to that user's operating system - instead of the user's having to choose between a long list of download buttons and operating systems ... I have also made a few apps for Firefox ... and my own keyboard layout where the computer decides which buttons do what. I have for instance decided that ALTGr+C makes a copyright symbol ..."

Adam is another example of a very interested, engaged student eager to learn ICT. He shows initiative and creative ways of approaching ICT. He experiments with producing a homepage and web apps while learning as he goes. His learning appears self-directed and is characterized by a proactive approach as he envisages potential users' needs when they engage with homepages, and his homepage design contains innovative solutions to the potential users' needs.

\section{Exiting - Towards new pedagogical avenues}

The dialogues with teachers and students from the two educational programs clearly indicate how some of the children and young people diagnosed with autism spectrum disorders are particularly resourceful when it comes to ICT and programming. Social robotics research appears to have dominated the area of research on robot technologies, autism and education. Furthermore, the social robotics research has engaged with the development and design of social robots as teaching assistants for children who are diagnosed with autism spectrum disorders and have severe communicative and social difficulties. This approach to researching robot technologies as educational technologies only covers a very limited aspect of what may be the creative potentialities of adding robot technologies to these children's and young people's educational activities. To return to McDermott, Verran, Castañeda and Suchman, I want to emphasize that, in relation to these Danish children and young people, these robot technologies need to be configured and corporealized in educational activities differently. These configurations and corporealizations include broader interests in the ICT interests and proficiency of children and young people diagnosed with autism spectrum disorders, as well as the constructionist engagements in robot technologies deployed in general education with a focus on technological literacy, Bildung, innovative and creative learning.

The stories of Violet, Michael, Peter, Adam and their teachers illustrate that there is "a group" of students diagnosed with autism spectrum disorders in both lower and upper secondary education who are particularly interested in and capable of working with ICT. These students' interests in ICTs may be a particularly interesting entrance to engaging with the learning and developmental challenges typically described by their teachers. The stories also illustrate, that the stereotypical characteristics of "autistic students" 
may be wrongly applied in general for these young people. They are clearly creative, inventive, engaged and motivated and show interest in perspectives other than their own - when it comes to ICT.

The ambitions in the new Danish school reform - which calls for future citizens that are creative, innovative, entrepreneurial and technologically literate - seem to offer a very interesting opening to education with robot technologies for this particular group of children and young people motivated by and interested and competent in ICT. In his seminal books "The Children's Machine - Rethinking School in the Age of the Computer" (1993b) and "Mindstorms - Children, Computers and Powerful Ideas" (1993a), Seymour Papert, who conceptualized the constructionist approach to learning, argues that a constructionist approach to learning implies creating spaces for unexpected ways of thinking and understanding - thinking that deviates from the norm. Creating spaces that provide access to students' microcosms is a central aspect of Papert's work. Papert sees this approach as the way to gain access to students' engagements in learning. Papert also emphasizes that special avenues of learning open up when students work by creating with technology. Teaching should scaffold the ways that students learn to think, solve problems, construct and be creative.

Examples of educational activities developed with inspiration from Papert's constructionism include 1990s computer Clubhouses (e.g., Rusk, Resnick and Cooke, 2009) and FabLabs (e.g., Blikstein, Martinez and Pang, 2015). A common feature of these activities is their emphasis on providing opportunities for children and young people to develop their own creative projects. This paper has demonstrated the need also to think in terms of constructionist-oriented designs for learning with robot technologies and other ICTs in educational programs for children and young people diagnosed with autism spectrum disorders.

\section{Conclusion}

As previously mentioned, the paper aimed to illustrate why we should engage with students diagnosed with autism spectrum disorders as whole and individual human beings that - like any other student - embody a complex multiplicity of dis/abilities and dis/engagements related to their personal interests and the daily course of their lives. A failure to pay attention to these heterogeneously constituted articulations of their dis/interests, competencies and preconditions would be a huge societal mistake.

This paper has focused on how ICTs - in this case robot technologies - in education and our ways of connecting them with children and young people diagnosed with autism spectrum disorders constitutively take part in enacting what it means to be challenged by and to learn from and with ICTs. The perspectives of the children and young people mentioned in this paper can in 
important ways contribute to the further development of designs for creative and innovative learning with robot technologies and other ICTs - designs that should include the perspectives of children and young people with special interests in engaging with learning by creatively designing and developing the technologies of the future.

\section{Referencer}

Alimisis, D. (ed.) (2009). Teacher Education on Robotics-Enhanced Constructivist Pedagogical Methods. School of Pedagogical and Technological Education (ASPETE). Patras, Greece. Located on www 27.12.2015:

http://dide.ilei.sch.gr/keplinet/education/docs/book_TeacherEducatio nOnRobotics-ASPETE.pdf

Alimisis, D. and Kynigos, C. (2009). Chapter 1 - Constructionism and robotics in education. In

Alimisis, D. (ed.). Teacher Education on Robotics-Enhanced Constructivist Pedagogical Methods. School of Pedagogical and Technological Education (ASPETE). Patras, Greece. Pages 11-26. Located on www 27.12.2015:

http://dide.ilei.sch.gr/keplinet/education/docs/book_TeacherEducatio nOnRobotics-ASPETE.pdf

Blikstein, P., Martinez, S. L. and Pang, H. A. (ed.) (2015). Meaningful Making: Projects and Inspirations for FabLabs and Makerspaces. Constructing Modern Knowledge Press. Torrance, CA USA. Located on www 22.12.2015: http://fablearn.stanford.edu/fellows/sites/default/files/Blikstein_Mart inez_Pang-Meaningful_Making_book.pdf

Brogaard Bertel, L., Rasmussen, D. M. and Christiansen, E. (2013). Robots for Real: developing a participatory design framework for implementing educational robots in real-world learning environments. In: Kotzé, P., Marsden, G., Lindgaard, G., Wesson, J. and Winckler, M. HumanComputer Interaction INTERACT 2013. 14th IFIP TC 13 International Conference, Cape Town, South Africa. September 2-6, 2013, Proceedings, Part II. (Vol. 8118), pages 437-444. SpringerLink Lecture Notes in Computer Science.

Bruun Jensen, C. (2004). Researching Partially Existing Objects: What Is an Electronic Patient Record? Where Do You Find It? How Do You study It? Working Paper no. 4. Centre for STS Studies, Department of Information and Media Studies, Aarhus, Aarhus University, Denmark. Located at www on 27.12.2015:

http://sts.imv.au.dk/sites/default/files/WP4_Jensen_Partially_Existing_ Objects.pdf

Bundsgaard, J., Petterson, M. and Puck M. R. (2015). Digitale kompetencer it i danske skoler i et international perspektiv. Aarhus, Aarhus Universitetsforlag, Denmark. 
Castañeda, C. and Suchman, L. (2014). Robot Visions. In Social Studies of Science. June 2014 (vol. 44), pages 315-341. SAGE Journals.

Cabibihan, J., Javed, H., Ang Jr, M. and Sharifah, M. A. (2013). "Why Robots? A Survey on the Roles and Benefits of Social Robots for the Therapy of Children with Autism. In International Journal of Social Robotics, 2013 (Vol. 5), Issue 4, pages 593-618. Springer.

Darsø, L. (2011). Innovationspædagogik - kunsten at fremelske innovationskompetence. Samfundslitteratur. Frederiksberg, Denmark.

De Laet, M. and Mol, A. (2000). The Zimbabwe Bush Pump: Mechanics of a Fluid Technology. In Social Studies of Science, (vol. 30), no 2, pages 225263. SAGE Journals.

Ebdrup, N. (2014). 'Mislykket' skole-robot lærer i virkeligheden eleverne at programmere. 18. november $2014 \mathrm{kl}$. 13:23. Lokaliseret på Videnskab.dk 22.10.2015: http://videnskab.dk/kultursamfund/mislykket-skole-robot-laerer-i-virkeligheden-eleverneprogrammere

Hansbøl, M. (2010). Researching relationships between ICTs and education: Suggestions for a science of movements. PhD thesis. Danish School of Education, Emdrup, Aarhus University, Denmark.

Hjorth, M., Sejer Iversen, O., Smith, R. C., Skov Christensen, K. and Blikstein, P. (2015). Digital Technology and design processes: Report on a FabLab@School survey among Danish youth. Aarhus, Aarhus University, Denmark.

Johnson, L., Adams Becker, S., and Hall, C. (2015). 2015 NMC Technology Outlook for Scandinavian Schools: A Horizon Project Regional Report. Austin, Texas: The New Media Consortium. Located at www 27.12.2015: http://cdn.nmc.org/media/2015-technology-outlook-scandinavianschools-EN.pdf.

Kärnä-Lin, E., Pihlainen-Bednarik, K., Sutinen, E. and Virnes, M. (2006). Can Robots Teach? Preliminary Results on Educational Robotics in Special Education. In Proceedings of the Sixth International Conference on Advanced Learning Technologies (ICALT'06). Pages 319-321. Kerkrade, Netherlands. IEEE.

Latour, B. (1999). Pandora's Hope: Essays on the Reality of Science Studies. Cambridge, Mass. USA. Harvard University Press.

Lave, J. and Wenger, E. (1991). Situated Learning: Legitimate Peripheral Participation. Cambridge, USA. Cambridge University Press.

Majgaard, G., Hansen, J. J., Bertel, L. and Pagh, A. (2014). Fra digitalt design til fysisk udtryk - anvendelse af 3-d-printere og NAO-robotter i Folkeskolen. In Tidsskriftet MONA - Matematik- og Naturfagsdidaktik, (nr. 4). Pages 7-26. Located at www 22.12.2015: https://insero.com/media/2972/mona-2014_4_fra-digitaltdesign.pdf 
McDermott, R. P. (1996). The acquisition of a child by a learning disability. In Chaiklin, S. and Lave, J. Understanding practice - Perspectives on activity and context. Cambridge, USA. Cambridge University Press. Pages 269-305

Mol, A. (2002): The Body Multiple: Ontology in Medical Practice. USA, Duke University Press.

Mubin, O., Stevens, C., Shahid, S., Mahmud, A. A. and Dong, J. (2013). A review of the applicability of robots in education. In Technology for Education and Learning. Located at www 20.10.2015: http://roila.org/wp-content/uploads/2013/07/209-0015.pdf

OECD (2009). 21st Century Skills and Competences for New Millennium Learners in OECD Countries. EDU Working paper no. 41. Located on www 04.04.2016:

http://www.oecd.org/officialdocuments/publicdisplaydocumentpdf/?c ote $=\mathrm{EDU} / \mathrm{WKP}(2009) 20 \&$ doclanguage $=\mathrm{en}$

OECD (2015). Students, Computers and Learning: Making the Connection, PISA, OECD Publishing. Located on www 27.12.2015: http://www.oecdilibrary.org/education/students-computers-andlearning_9789264239555-en

Partnership for 21st Century Learning (2007). Located on www. 04.02.2016: http://www.p21.org/about-us/p21-framework

Papert, S. (1990). A critique of technocentrism in Thinking about the School of the Future. Located at www 22.10.2015: http://www.papert.org/articles/ACritiqueofTechnocentrism.html.

Papert, S. (1993a). Mindstorms - Children, Computers and Powerful Ideas. Second Edition. New York, USA. BasicBooks.

Papert, S. (1993b). The Children's Machine - Rethinking School in the Age of the Computer. New York, USA. BasicBooks.

Rusk, N., Resnick, M. and Cooke, S. (ed.) (2009). Chapter 1. Origins and Guiding Principles of the Computer Clubhouse. In Kafai, Y. B., Peppler, K. A. and Chapman, R. N. The Computer Clubhouse - Constructionism and Creativity in Youth Communities. New York, USA. Teachers College Press. Located at www

22.12.2015: http://citeseerx.ist.psu.edu/viewdoc/download?doi=10.1.1 $.141 .5830 \&$ rep $=$ rep $1 \&$ type $=$ pdf

Strathern, M. (2004). Partial Connections: Updated Edition. Walnut Creek, CA. AltaMira Press. Originally published in 1991 by the Association for Social Anthropology in Oceania.

UNESCO (2008). UNESCO's ICT competency standards for teachers. Located at www 04.02.2016: http://cst.unescoci.org/sites/projects/cst/default.aspx. 
Verran, H. (2007). Metaphysics and learning. In Learn Inquiry, 2007 (Vol. 1) Issue 1. Pages 31-39. Springer.

Wainer, J., Dautenhahn, K., Robins, B. and Amirabdollahian, F. (2014). A Pilot Study with a Novel Setup for Collaborative Play of the Humanoid Robot KASPAR with children with autism. In International Journal of Social Robotics, 2014 (Vol. 6), Issue 1, pages 45-65. Springerlink.com.

World Health Organization (2016). International Statistical Classification of Diseases and Related Health Problems 10th Revision (ICD-10). Version for 2016.

Located at www 17.12.2015:

http://apps.who.int/classifications/icd10/browse/2016/en

\footnotetext{
'See: http://www.autismeforening.dk/autismeForening.aspx?linkld=1.

"Via library UCSJ (International journals) and Google. Search terms "robot technology + education", "robot technology + inclusion + education", "robot technology + autism", "social robotics + education", "social robotics + review", "social robotics + autism", "social robotics + autism + education".

iii Conducted as separate activities in respectively 2012 and 2015. All names of students, teachers and institutions have been anonymized. All transcripts of interviews and conversations have been translated by the author from Danish to English.

${ }^{\text {iv }}$ E.g. The municipalities of Ringsted (http://ringsted.dk/nyheder/borger/robotbier-nyteknologi-i-boernehoejde), Lolland (http://folketidende.dk/Lokal-nyt/Lolland-Kommunesatser-paa-robotter/artikel/291878) and Faxe (http://www.faxekommune.dk/nyhed/robotterne-flytter).

${ }^{v}$ Danish companies like Blue Ocean Robotics continuously alter their marketing of robots for education. See e.g. http://www.blue-ocean-robotics.com/da/produkter.

vi In Danish: STU - Særligt tilrettelagt ungdomsuddannelse. See: https://www.europeanagency.org/country-information/denmark/national-overview/special-needs-educationwithin-the-education-system.
} 